\title{
The UK Teaching Excellence Framework (TEF) as an illustration of Baudrillard's hyperreality.
}

\author{
John Canning
}

Centre for Learning and Teaching and Education Research Centre, University of Brighton, Brighton, UK. BN1 9PH

j.canning@brighton.ac.uk

$+44(0) 1273642774$

\begin{abstract}
This article examines the 'Teaching Excellence Framework' (TEF) for UK universities through the lens of Jean Baudrillard's concept of hyperreality. I argue that the TEF is a hyperreal simulacrum, a sign which has no traceable genealogy to the practice of learning and teaching.
\end{abstract}

Keywords: Baudrillard, Teaching Excellence Framework, hyperreality, teaching quality

In UK higher education the view that financial outcomes and prestige for both individuals and institutions are bound almost entirely in research rather than teaching leads to the inevitable question of how this imbalance should be addressed; a system where academics are rewarded more for research than for teaching, and institutions rewarded financially for the quality of the research rather than their teaching can lead to a situation where the teaching of students is neglected.

The latest attempt to readdress this imbalance in UK higher education comes in the form of the Teaching Excellence Framework (TEF) launched by Higher Education Minister Jo Johnson in September 2015 and expounded in November 2015's Government Green Paper, Fulfilling our Potential: Teaching Excellence, Social Mobility and Student Choice (Department for Business, Innovation and Skills, 2015) and the subsequent White Paper, Success as a Knowledge Economy: Teaching 
Excellence, Social Mobility and Student Choice (Department for Business, Innovation and Skills, 2016). The UK ${ }^{\mathrm{i}}$ has had central evaluation of research since the 1980s through the Research Assessment Exercise (RAE) then the Research Excellence Framework (REF). An earlier Government White Paper (Department of Business Innovation and Skills 2011) had aspirations for a system in which there might be a REF equivalent for teaching in higher education.

The idea that research and teaching can be evaluated using similar underlying principles is not new (see Gibbs 1995, 2010) and tensions surrounding the reward for universities and individuals for the quality of their teaching and the quality of their research is not a new discussion (see Drennan 2001). Debates around assessing the quality of teaching include everything from the direct observation of teaching, reward and recognition of individuals and universities, student evaluations and quality assurance processes (See Harvey and Williams 2010a, 2010b for a worldwide overview).

The TEF is not the first national attempt at assessing teaching quality in UK higher education. The Teaching Quality Assessment (TQA) ran from 1993-1995 and looked at the quality of teaching and learning at an institutional level (Cheng 2010, p. 259). Subject Review (1995-2001) focused on departments and involved the observation of teaching, examining student work and scrutinising institutional and departmental quality processes (Gosling and D’Andrea 2001, p. 8). In interviews with 64 academics who experienced subject review, Cheng (2010, p. 262) found a large degree of ambivalence towards the process, with 30 interviewees reporting both negative and positive impacts on their teaching. Since 2001, there has been a range of quality assurance and quality enhancement initiatives through the Quality Assurance Agency (QAA) institutional audit, the National Student Survey (NSS) and a range of activities and funding streams such as the Fund for the Development of Teaching and 
Learning (FDTL), the Learning and Teaching Support Network (LTSN) and the Higher Education Academy (HEA). Gosling’s 2004 evaluation of the Teaching Quality Enhancement Fund (TQEF) under which these various initiatives were drawn together is still valid:

. ...any effect on the student experience of higher education remains largely unknown, and still less is known whether this activity has improved student learning or the outcomes of their learning in any way. Evaluations have focused on changes to institutional behaviours rather than on improvement of quality of teaching and learning. (Gosling 2004, p.146, emphasis added).

However, the Minister has stated:

I have no intention of replicating the individual and institutional burdens of the REF. I am clear that any external review must be proportionate and light touch, not big, bossy and bureaucratic. (Johnston 2015).

This article explores the TEF through the perspectives of French social theorist Jean Baudrillard (1929-2007), notably his work on the concept of hyperreality. The volume and nature of Baudrillard's work makes him difficult to pin-down as a theorist though like his contemporaries Jacques Derrida (1930-2004), Michel Foucault (19261984), Giles Deleuze (1925-1995), Felix Guattari (1930-1992), Pierre Bourdieu (19302002), and Jean-François Lyotard (1925-1998) he is often labelled as a 'poststructuralist thinker'.

Baudrillard's extensive use of concrete examples, such as Disneyland, specific TV shows, advertising campaigns and political events makes his work more accessible than many of his contemporaries. The examples of simulation can readily lead to the identification of further examples as the postmodern world is one in which signs abound. 
In Baudrillardian thought the hyperreal is the third order of simulation. If we imagine 'pure reality' as a 'core' this reality is surrounded (or potentially surrounded) by multiple 'orders' (or layers ) of simulacra of that reality . Baudrillard outlines illustrations of these orders of hyperreality in the opening chapter of Simulacra and Simulation (1994[1981]). (To add further complications these orders of simulation have a historical dimension in which the layers develop over the course of the shift from premodernity, to modernity then to post-modernity.) Baudrillard illustrates this point by referencing Borges' one paragraph short story On Inexactitude in Science (1975 [1946]). An example of the first order of simulation is the familiar map. A map is representation of a geographical territory. It is not reality itself, but represents a reality. The second order is where in an effort to represent a fictional empire in its full glory, cartographers produce a map which is the same size and contains all the same detail as the empire itself - thus in the second order of the simulacra the real and representation of the real can no longer be distinguished. The third order is the hyperreal of which Baudrillard regarded Disneyland to be an apt illustration. For example the castles at Disneyland are real castles and they do not represent real castles outside Disneyland. Moreover while visitors recognise the Disneyland castles as castles they are actually idealised constructions of castles, an idea about what castles should be like. The hyperreal is a detachment from both reality and representation, 'a real without origin or reality' (Baudrillard 1994[1981], p. 2).

\section{Baudrillard and education}

In contrast to his contemporary Bourdieu, there has been relatively little work in applying Baudrillard's ideas to education, whether by educationalists or by Baudrillard specialists. In one of the relatively few explicit treatments of Baudrillard's work in educational research, Moran and Kendall argue that most educational research reproduces simulations rather than reporting on any reality: 
An investigation of education? No: the researchers and the methodologies that they deploy are likewise engaged in the similar act of forgery, a similar manufacture of presuppositions about what education is. There is no real education, no real of education, no real about education; all that we have are a series of forgeries; an endless number of simulations; all with no real anchor point in the real, because there isn’t one. (Moran and Kendall 2009, p.327)

These simulations of education rely on an underlying assumption that there is a real of ‘education’ which not only exists independently of curricula, testing regimes, social, economic and cultural differences etc., but can also be known through artefacts such as policies and procedures (Moran and Kendall 2009 , p.333).

\section{A case study of the UK Teaching Excellence Framework}

One of the differences between the REF and the TEF is that the REF has a distinct traceable genealogy of reality and representation. Although the details of the REF's history and evolution is beyond the scope of this article, the REF is traceable to actual research practices through publication, environment or impact (REF 2014). The REF is criticised for being expensive to administer in terms of time and money (Farla and Simmonds 2015), being biased in favour or against certain types of research and being unfair to particular groups of staff, notably women, ethnic minorities and early career researchers (see Murphy and Sage 2015). REF has given rise to a new language where researchers and individual pieces of work are described as 'refable'. 'Refability' can depend as upon the perceived status of the journal in which the research is published as well as the perceived importance of a particular topic at a particular time. These rules are largely tacit and in most disciplines unclear. However at the crux of the REF, actual research papers and research practices lie.

However, while the REF has a strong research element, the TEF has no traceable teaching elements. The metrics used are the Destination of Leavers from Higher 
Education (DLHE) - the logic that students who are taught well will get good jobs; the National Student Survey (NSS)- the idea that the students who are taught well will be satisfied with the education they have received and continuation rates- students who are taught well will not drop out of their studies (Department for Education 2016, p. 66).

The justification for using existing metrics is to make the exercise 'light touch' avoiding the increasing bureaucracy which has blighted the REF. We are informed that measuring the 'excellence' of teaching won't involve much work on our part. There is no place for scholarship(s) of learning and teaching (SoTL), whether through academic reflection on teaching, engaging with the evidence surrounding specific teaching practices in particular disciplinary contexts or conducting and publishing research into teaching and learning (see Healey 2000). Therefore universities will not be rewarded on the quality of the teaching (let alone learning) which takes place, but upon the metrics (ghosts) of measurements which may or may not reflect the quality of teaching. As an aside, the unit of analysis is currently the university, not individuals or departments within the university. Pragmatically speaking, whatever definitions of 'teaching excellence' we use there is going to be considerable variation of 'excellence' between individuals and departments, and the reasons for these variations will be extremely complex.

Additionally, the TEF itself is without scholarly underpinning and does not seek to promote pedagogic research, nor encourage scholarly approaches to developing teaching. Quantifiable metrics with specific targets and outcomes as the key drivers of learning and teaching policy conflict directly with student-staff partnerships which value process and unexpected outcomes (Healey et al 2014, p. 58). This emphasis on product variables (e.g. employability outcomes) and presage variables (e.g. universities with a good reputation attract the 'best' (or more advantaged) students who are thereby 
academically successful and have good employability outcomes), leads to a neglect of process:

\begin{abstract}
What best predicts educational gain is measures of educational process: what institutions do with their resources to make the most of whatever students they have. The process variables that best predict gains are not to do with the facilities themselves, or to do with student satisfaction with these facilities, but concern a small range of fairly well-understood pedagogical practices that engender student engagement. (Gibbs 2010, p. 5).
\end{abstract}

In Baudrillard's terms REF has research (the real), a REF submission (a first order simulacrum), the REF assessment and scores, a second order simulacrum where the real (the research) and the representation of the research (the REF submission), are confounded and indistinguishable. If the TEF was really 'a REF for teaching' it would start at the point of teaching (the real) followed by some sort of representation of teaching (the first order of simulation), followed by an assessment of that submission whereby the teaching and TEF submission would become confounded in the second order of simulation. However the TEF is hyperreal as it is detached from both reality and representation, namely the practice of teaching in higher education and the evaluation/ assessment of that teaching. Aware that the experience is not 'real', senior managers and the Government alike recognise that the TEF is not real when it comes to measuring teaching excellence which leads to 'cognitive dissonance' (Healey et al 2014, p. 58).

However, the hyperreality of the TEF enables university leaders to increase fees and enhance the reputation of their universities while the Government can show that it is committed to ensuring good teaching standards in university. Part of the narrative of why the TEF is deemed necessary lies in the unintended consequences of the REF and its predecessor which has led to both individual academics and universities collectively 
being rewarded more for being good at research than good at teaching. The public (including potential students) enter into this hyperreal as they are expected to assume that a university's TEF outcomes have some relationship with the practice of teaching in a situation where no teaching has been systematically researched, observed or evaluated. Returning to the thoughts of Moran and Kendall above, 'teaching excellence' does not exist independently of the measures used to define it. TEF does not measure 'teaching excellence'; rather it defines teaching excellence in accordance with the metrics available,

\section{Improving the score}

A second way in which the TEF is hyperreal lies in the way the internal university discourse increasingly focuses on matters of improving scores rather than examining the circumstances which may lead to these scores. While the NSS is highly problematic as a quality tool there is little doubt that better teaching can and does lead to higher levels of student satisfaction, yet the emphasis is put on the need to improve scores and climb up the league tables. The actual materiality of higher placings does not need to be explained - and therein lies the problem. NSS scores, or any other score for that matter do not require improvements because higher scores indicate that teaching is better, but increased scores acquire a value independent of what they are supposed to be measuring. Williams correctly states, 'Lecturers should feel confident to remind students that genuinely engaging in intellectual struggle is not intended to be immediately satisfying' (Williams 2012, p. 149), but happiness and desires are the basis on which consumerist society stands or falls (Bauman 2007, p. 44). 


\section{The Discourse of the TEF}

\section{Good teaching and the evaluation of teaching}

In the 1980s British political comedy Yes Minister, the civil servant Sir Humphrey Appleby points out that the way to obscure what you what to do is to take care of it in the title.

Sir Humphrey: Well, Yes always dispose of the difficult bit in the title; it does less harm there than in the text.

Sir Arnold: It's the law of inverse relevance; the less you intend to do about something the more you have to keep talking about it. (Jay and Lynn 1980).

The TEF is especially effective in this regard. 'Teaching Excellence' implies that some sort of evaluation of teaching will take place, otherwise we couldn't know if it was excellent, yet, as argued above the TEF is a third order simulation which has no genealogy to actual teaching practice. As the TEF is so new, the analysis which follows comes from newspapers and academic blogs. Plowden (2015) argues that the TEF holds no fear for those who teach well and while he is cautious about metrics, he essentially takes the phrase 'Teaching Excellence Framework' at face value assuming that the framework will somehow evaluate the teaching practice of individuals. Canning (2015) warns against a compulsory-sector inspired OFSTED ${ }^{\mathrm{ii}}$ approach in which the solution to inadequate and partial metrics has been the collection of more metrics. However, OFSTED does actually visit schools and observe the practice of teaching in schools, something which, the TEF shows no indication of doing at present. TEF is therefore a copy, a representation of something which does not exist.

\section{Running the TEF better}

The UK’s Higher Education Academy (HEA) which describes itself as '...the national 
body which champions teaching quality' (HEA 2016), is funded through subscriptions from member universities in the UK and beyond. Its Chief Executive notes there is no national or international definition of 'teaching excellence'. She also notes that current metrics are not designed for the purpose of assessing teaching in any form (Marshall 2015).

Marshall also recommends that the TEF include peer reviewed case studies of practice. In Baurdillardian terms she could be seeking to push the TEF from a third order simulacrum to a first or second order simulacrum. The proposed 'case studies' will be representations of teaching practice which may or may not bear a great deal of resemblance to the real, but at least the case studies would be traceable from teaching practice. However, the cost of this evaluation would come in the form of more bureaucracy and subjective judgement, which appears to be a violation of the TEF as a light-touch exercise. The Interim chief of the UK’s Quality Assurance Agency (QAA), which advises higher education institutions on quality and standards, has taken a similar view (Havergal 2015).

Drawing on Baudrillard's conception of reterritorialisation, Webb describes conformity with such accountability systems as 'epistemological suicide' committed '...when surveillance technologies, masked as performance-based accountability systems, demand evidence of their knowing.' Webb (2007, p. 279). This discourse of conformity is evident through the reporting of the TEF through the media.

\section{Power relations and the media}

Baudrillard was particularly interested in the media and since his death in 2007 media has changed dramatically through the advent of social media such as the microblogging site Twitter TM ${ }^{\text {}}$ Additionally, there have been numerous media articles, 
blog posts and conversations in professional organisations, in universities and meetings with the minister himself. For example, as this tweet from Elizabeth Cleaver, Chair of the Heads of Educational Development Group (HEDG) states:

Elizabeth Cleaver @Ecleaver, 3 September 2015

Travelling down to Westminster today to speak with Jo Johnson, Minister for Universities and Science about the \#TEF \#teachingexcellence

Cleaver offers no update or comment on her meeting with the minister; the knowledge that she is going to meet him and has presumably met him to speak about the TEF is an important part of the hyperreality of the TEF. Baudrillard (1994 [1981], p. 30) writes of the Loud family, the subjects of the first Reality TV show in 1971 which consisted of 300 hours coverage over seven months with no script and no plot, just raw 'reality' in the life of an American family watched by 20 million people. Cleaver's tweet about her meeting (or a confirmation that she is on a journey and expects to meet the minister) is one of thousands of utterances about what the TEF will or will not be is indicative of the hyperreality of the TEF. Cleaver's distinction as one of just four people invited to meet the Minister for Universities and Science' to discuss the TEF, features predominately on her online profile for her work for Academic Audit Associates. ${ }^{\mathrm{iii}}$ It is easy to find out that a meeting took place between Cleaver and Johnson, but it is not possible to find any report of the meeting itself. There is no narrative working its way towards a conclusion. Are we amusing ourselves to death (Postman 1985) not through 'showbusiness' but through speculation about what the TEF might become? 'Without a medium to create its form news of the day does not exist.' (Postman 1985, p. 8).

Today with hundreds of TV channels, the internet and social media, audiences are more fragmented. I can discuss matters of personal concern on Twitter with others 
interested in same topics, while other people focus on topics of interest to them.

Although the TEF is unlikely to make the 'news of the day' in the way Postman understood, I am a participant and observer in an unfolding drama, albeit one in which relatively few people are interested.

In The Gulf War did not take place, Baudrillard (1995[1991], p.45) presents that event as a media war, played out on television as a 'clean' war in which the process of communication itself 'excludes any violent or personal affect'. The speed of information moves so fast, that all sense is lost, and any new information is forgotten by the next day, so no one is ever held to account for their actions (Baudrillard 1995 [1991], p. 49-51).

\section{Broader relevance beyond the TEF}

The TEF is illustrative of the tendency for politicians to offload the implementation of political projects onto others, seen as 'expert' (Hay and Stoker 2009). Although set up by Government, the detail of implementing and running the TEF has been given to the funding councils and the universities themselves to implement. While the power of non-elected bodies can be seen as undemocratic, it is also indicative of politicians responding to public distrust in elected officials by handing implementation over to other 'arms-length' organisations. It is also symptomatic of successive UK Government’s tendency to radically change higher education 'every three-four cohorts of new entrants', a characteristic of the UK on which only Australia can compete (Watson 2015, p. 551).

1. Government still needs and wants to be involved in the running of UK universities, but needs to do this at a distance (the cost of a university education has been transferred from the taxpayer to the individual student over the past 25 years). At present the UK government maintains its interest in universities through funding for research and a subsidised loan system for students. Although universities which perform 
well on the TEF will be able to increase fees, this increase will only be in line with inflation. There is talk of other rewards though these are not clear at present. Thoughts of privatisation of UK universities with up front student payments or student loans to fund market rate fee levels do not appear to have become any more likely than they were five years ago.

2. The TEF is a simulation, a third older simulacrum, a copy of which no original exists. As presently conceived the framework is a series of measurements that are not informed by teaching practice which takes place in the university. However, the TEF will be presented as a narrative of what actually happens in a university.

3. Following on from 1 and 2 academics either consciously or subconsciously are led to believe that the TEF can be improved so that it can become a representation of a reality rather than a hyperreal simulation of a non-existent reality. There are two possible futures here: either the TEF remains hyperreal in the longer term, or it evolves into a bureaucracy which could be a) school-inspection like or b) REF-like. The scandal will not be that research is considered more important teaching in universities, but that the scandal can be covered up by a light-touch metrics system.

Drawing on Moran and Kendall (2009, p.328) it is possible to see these attempts to engage with the TEF on its own terms as a delusion. If TEF is to be regarded as a legitimate or potentially legitimate measure of a reality called 'teaching excellence' we need to delude ourselves and others that a) teaching excellence exists independently of any social construction of teaching excellence and b) that teaching excellence can be evaluated and measured to bring about improvements. The 'improvements' or 'enhancements' are therefore themselves hyperreal as they are constructed and evaluated on the basis of a reality which does not exist.

\section{Broader lessons for higher education beyond the TEF}


Looking to Baudrillard for a policy response is not likely to be a productive pursuit. His oeuvre exposes power relations and the nature of postmodernity, but cannot be said to offer anything resembling a coherent political project. In a 1985 interview, responding to the socialist French government's call to intellectuals, he observed.

Intellectuals are now biding their time because there is no real dialogue nor any real discussion. Each person is doing his or her own thing, attached to his or her own research or a group. (Baudrillard 1993 [1985], p.73)

Kemmis (1995) characterises post-structuralist theorists as being distant from human and social affairs and draws upon Friere's critical pedagogy (Friere 1996 [1970]), to explore emancipatory approaches to pedagogy which are inspired by Friere but not restrained by the specifics of Friere's theories. So whereas Baudrillard seems to offer little possibility for a political project, Friere offers hope which extends beyond his cultural, historic and even theoretical context.

Developing the idea of intellectual identity as one of opposition and not of power, Baudrillard contrasts his situation with what he calls 'third world' intellectuals who 'have the privilege of holding a clear critical position and of having the possibility of struggle (1993 [1985], p. 73). In contrast the post-modern society is one in which power dissipates and fragments while obsession with preservation of power grows.

Drawing on Baudrillard's earlier work ( 2001b [1968]), Casey (2011) develops Marx's concept of the commodity fetish from one situated in political economy to a cultural one based on the generation of signs and the need to consume in order to be culturally fulfilled. He sees the commodity fetish manifested in how students themselves become a commodity with exchange and use value. The needs of students are constructed to the requirements of the society in which they live and not to their intrinsic human needs Casey (2011, pp. 79-80). 
It is possible to draw a parallel with the drive for universities to provide information by which students can make informed choices about where to study. The Key Information Set (KIS) (HEFCE 2015) is a collection of data on matters as varied as results from the NSS, contact hours, and coursework/exam balance through to local accommodation costs. The TEF is a distinct next stage whereby students can choose their university on the basis that it teaches well (or must teach well because it performs well on certain measures). To take Casey's (2011) work to its natural conclusion universities are not only commodities to sell to students while students simultaneously are commodities produced by universities. The assumption that students are consumers, concerned only with the product informs pedagogic practices contributing to a 'vicious circle', whereby teachers emphasise perceived student 'need' over passion or interest in the subject (Williams 2012, p. 93).

TEF is also illustrative of deterritorialisation of teacher knowledge. 'Ecstasy is that quality specific to each body that spirals in on itself until it had lost all meaning.' (Baudrillard 2001a [1983], p. 190). The ecstatic form of pedagogy is 'anti-pedagogy' which is 'the pure and empty form of pedagogy.' (ibid). In this 'anti-pedagogy' the knowledge and expertise of teachers is no longer required and is actually presented as the enemy of good teaching. (Webb 2007, p. 284)

For example, in a metric such as DLHE universities not only produce commodities to sell which meet the needs of society (graduates), but need to 'buy' (recruit) commodities that can be transformed into commodities post-capitalist society requires. Moton and Harney (2004, p.104) take this to a further level of complexity. The follow up to the 'student as customer' is not that 'the customer is always right', but the customer sees themselves as part of the problem:

...which counter to the complaining of restorationalist critics of the university, is precisely what it means to be a customer, to take on the burden of realization and 
always be inadequate to it. Later, these students will be able to see themselves properly as obstacles to society, or perhaps, with lifelong learning, students will return having successfully diagnosed themselves as the problem. (Moton and Harney 2004, p. 104)

In recognising their university is excellent at teaching (as measured by the TEF), dissatisfied students will see any shortcomings as their own fault and, ironically, will come back to the source of their dissatisfaction for further study. This illustrates how in a society of signs, order turns in upon itself and the real and represented are no longer distinguishable. In his translator's introduction to Baudrillard's The Gulf War Did Not Take Place, Patton recalls a moment when:

... the CNN cameras crossed live to a group of reporters assembled in the Gulf, only to have them confess than they were sitting round watching CNN in order to find out what was happening (Patton 1995, p.2).

Similarly rather than focusing on the quality of teaching and looking to the TEF to provide some sort of measurement of quality, we are looking to the TEF to improve our teaching practices. The TEF does not aim to be a solution to poor teaching in universities or even a means to help students make choices, but a means to promote the TEF itself as the guardian of good teaching, in the same way Baudrillard understood the Gulf War not be about winning a war, but proving the infallibility of the US war machine. (Baudrillard 1995 [1991], p. 55).

At the same time the TEF can defend universities against accusations of poor teaching —if the student does not learn as well as they should they only have themselves to blame. However, with reference to international PISA (Programme for International Student Assessment) tests Serder and Ideland (2016) observe how poor education is 'constructed' as the tests have become a 'taken for granted' measure in comparing international educational standards. PISA represents a truth about a society's education 
system which cannot be debated. Consumers can be equal with regards to the use value of an object (e.g. an education), but not all consumers are 'equal before objects as sign and differences, which are profoundly hierarchical' (Baudrillard 1998 [1970], p. 90).

\section{Conclusions}

Firstly, Baudrillard's notion of hyperreality offers insights into the mechanism by which we, as academics, teachers and educational researchers are drawn into debates about matters such as the TEF on the same terms as those who to maintain influence on universities through seemingly objective measures of quality assurance. By using the language of 'teaching excellence' and regarding it as something which can be objectively measured we deprive ourselves of the language which can be lead to genuine improvements in education. Whenever we seek to improve the TEF (or any other regime) by suggesting we change the evaluation metrics, we deprive ourselves of the possibility of change. Baudrillard (and others) expose the signs that do not represent anything. By employing the language of 'teaching excellence' we become constricted by the quality regimes which reward and constrain our practice and dehumanise our students.

Secondly, inspired principally by Moran and Kendall (2009) we need to rethink the ways in which we conduct pedagogic research. While empirical approaches to educational research are valuable they can leave us constrained by the terms of imposed regimes whether in the form of national curricula or the constraints of course structure in universities thereby offering no improvement in practice which extends beyond anything which can be measured objectively (e.g. by students grades) over a short period of time (e.g. one semester, one academic year). Concern about matters such as student grades have not led to a rethink about how we do educational research, but to an increased obsession with standardised testing as objective measures to break the subjectivity of student grades (as critiqued by Serder and Ideland 2016). 
Thirdly, we might consider the view that surveillance regimes such as TEF have nothing to offer in terms of improving teaching and we should not get drawn into discussions around its operation and encourage others to see the TEF as a simulacrum.

\section{References}

Baudrillard, J. (1994) Simulacre and Simulation (S.F. Glaser, Trans.). Ann Arbour. University of Michagan Press. Original 1981.

Baudrillard, J. (1993) Intellectuals, commitment and political power. Interview with Maria Shevtsova (M. Shevtsova, Trans.). In M. Gane (ed.) Baudrillard Live: Selected interviews. (pp.72-80). London. Routledge. Original 1985

Baudrillard, J. (1995). The Gulf War did not take place. (P. Patton, Trans.) Bloomington \& Indianapolis. Indiana University Press. Original 1991.

Baudrillard, J. (1998). The Consumer Society: Myth and Structures. (C. Turner, Trans.) London. Sage. Original 1970.

Baudrillard, J. (2001a). Fatal Strategies. (J. Mourrain, Trans.) In M. Poster (ed.) Jean Baudrillard: Selected writings. (pp.188-209). Cambridge. Polity. Original 1983.

Baudrillard, J. (2001b). The System of Objects. (J. Mourrain, Trans.) In M. Poster (ed.) Jean Baudrillard: Selected writings. (pp.13-31). Cambridge. Polity. Original 1968.

Bauman, Z. (2007). Consuming Life. Cambridge. Polity.

Borges, J. L. (1999). On Inexactitude in Science. (A. Hurley, Trans.) In Collected Fictions. New York: Penguin. p.325

Canning, J (2015, July 13) What's worse than a Ref for teaching? An Ofsted for universities. The Guardian. Retrieved from: http://www.theguardian.com/higher-education-network/2015/jul/13/whatsworse-than-a-ref-for-teaching-an-ofsted-for-universities

Casey, Z. A. (2011) Toward a Reconceptualization of Needs in Classrooms: Baudrillard, Critical Pedagogy, and Schooling in The United States. Journal for Critical Education Policy Studies 9, 77-87. Retrieved from http://www.jceps.com/wpcontent/uploads/PDFs/09-2-05.pdf 
Cheng, M. (2010). Audit cultures and quality assurance mechanisms in England: a study of their perceived impact on the work of academics. Teaching in Higher Education 15, 259-271. doi:10.1080/13562511003740817

Department for Business, Innovation and Skills (2011) Higher Education: Students at the Heart of the System. Sheffield: BIS

Department for Business, Innovation and Skills (2015) Fulfilling our Potential: Teaching Excellence, Social Mobility and Student Choice. Sheffield: BIS

Department for Business, Innovation and Skills (2016) Success as a Knowledge Economy: Teaching Excellence, Social Mobility and Student Choice. London: BIS

Department for Education (2016) Teaching Excellence Framework: year two specification. London, DfE.

Drennan, L. T (2001). Quality Assessment and the Tension between Teaching and Research. Quality in Higher Education, 7, 167-178 doi: $10.1080 / 13538320120098050$

Farla, K, \& Simmons, P. (2015). REF 2014 Accountability Review: Costs, Benefits and Burden. Brighton: technopolis group. Retrieved from http://www.hefce.ac.uk/media/HEFCE,2014/Content/Pubs/Independentresearch/ 2015/REF,Accountability,Review,Costs,benefits,and,burden/2015_refreviewcost s.pdf.

Freire, P. (1996). Pedagogy of the Oppressed. (M. Ramos, Trans.) London. Penguin. Original 1968.

Gibbs, G. (1995). The Relationship Between Quality in Research and Quality in Teaching. Quality in Higher Education. 1, 147-157. doi:10.1080/1353832950010205

Gibbs, G. (2010). Dimensions of Quality. York. Higher Education Academy.

Gosling, D., \& D’Andrea, V-M. (2001). Quality Development: a new concept for higher education. Quality in Higher Education. 7, 7-17. doi:10.1080/13538320120045049 
Gosling, D. (2004). The impact of a national policy to enhance teaching quality and status, England, the United Kingdom. Quality Assurance in Education. 12, 136149. doi:10.1108/09684880410548762

Gunn, V. (2016) The TEF and HERB cross the devolved border (Part 2): the paradoxes of jurisdictional pluralism. SHRE blog: Retrieved from: https://srheblog.com/2016/12/01/the-tef-and-herb-cross-the-devolved-borderpart-2-the-paradoxes-of-jurisdictional-pluralism/

Havergal, C. (2015, October 8). TEF must include independent peer review, says new QAA chief. Times Higher Education Retrieved from: https://www.timeshighereducation.com/news/douglas-blackstock-qaa-teachingexcellence-framework-tef-must-include-independent-peer-review

Harvey, L. \& Williams, J. (2010a). Fifteen Years of Quality in Higher Education. Quality in Higher Education. 16, 3-36. doi:10.1080/13538321003679457.

Harvey, L. \& Williams, J. (2010b). Fifteen Years of Quality in Higher Education (Part Two). Quality in Higher Education. 16, 81-113. doi:10.1080/13538322.2010.485722.

Hay, C. \& Stoker, G. (2009). Revitalising Politics: Have We Lost the Plot? Representation 45, 225-236. doi:10.1080/00344890903129681

Healey, M. (2000) Developing the Scholarship of Teaching in Higher Education: A discipline-based approach, Higher Education Research \& Development, 2, 169189. doi:10.1080/072943600445637

Healey, M., Flint, A. \& Harrington, K. (2014). Engagement through partnership: students as partners in learning and teaching in higher education. York, Higher Education Academy.

HEFCE (2015) Unistats and the Key Information Set. Retrieved from http://www.hefce.ac.uk/lt/unikis/

Jay, A \& Lynn, J .(Writers), \& Lotterby, S. (Director). (1980). Open Government. In Lotterby, S. (Producer), Yes Minister. London, UK: BBC

Johnson, J. (2015, September 9). Higher education: fulfilling our potential. [Speech] Department for Business, Innovation \& Skills Retrieved from https://www.gov.uk/government/speeches/higher-education-fulfilling-ourpotential 
Kemmis, S. (1995). Emancipatory Aspirations in a Postmodern Era. Curriculum Studies 3, 133-167. doi:10.1080/0965975950030203.

Marshall, S. (2015, 5 October). Proposing a sustainable Teaching Excellence Framework, Wonkhe Retrieved from http://wonkhe.com/blogs/proposing-asustainable-teaching-excellence-framework/

Moton, F. \& Harney, S. (2004) The University and the Undercommons: SEVEN THESES. Social Text Summer 200422 (2 79): 101-115; doi:10.1215/0164247222-2_79-101

Moran, P. \& Kendall, A. (2009). Baudrillard and the End of Education. International Journal of Research \& Method in Education, 32, 327-35. doi:10.1080/17437270903259873.

Murphy, T. \& Sage, D. (2015). Perceptions of the UK’s Research Excellence Framework 2014: A small survey of academics. Australian Universities' Review, 57, 231-36.

Patton, P (1995) Introduction. In: Baudrillard, J. (1995). The Gulf War did not take place. (P. Patton trans.) Bloomington \& Indianapolis. Indiana University Press. Original 1991.

Plowden, P. (2015, 25 August) How to approach the Teaching Excellence Framework with confidence. The Guardian http://www.theguardian.com/higher-educationnetwork/2015/aug/25/how-to-approach-the-teaching-excellence-frameworkwith-confidence

Postman, N. (1985) Amusing ourselves to death. London: Penguin.

REF (2014) Guidance and criteria http://www.ref.ac.uk/about/guidance/ Accessed 20/4/16

Serder, M, \& Ideland, M. (2016). 'PISA Truth Effects: The Construction of Low Performance'. Discourse: Studies in the Cultural Politics of Education 37: 34157. doi:10.1080/01596306.2015.1025039.

Watson, D. (2015) The Coming of Post-Institutional Higher Education. Oxford Review of Education, 41, 549-562. doi:10.1080/03054985.2015.1077110 
Webb, P. T. (2007) Accounting for Teacher Knowledge: Reterritorializations as

Epistemic Suicide. Discourse: Studies in the Cultural Politics of Education, 28, 279-95. doi:10.1080/01596300701289409

Weiss, M. G. (2011) Reality, Simulation and Hyperreality: An Essay on Baudrillard. International Journal of Baudrillard Studies 8. Retrieved from http://www2.ubishops.ca/baudrillardstudies/vol8_2/v8-2-weiss.html

Williams, J. (2012) Consuming Education: Why Learning Can't be Bought. London. Bloomsbury.

Acknowledgements: I would like to thank Andrew Hobson, Joel Roberts and Christopher De Thorpe Millard for comments and discussions on earlier drafts of this article.

\footnotetext{
${ }^{i}$ Although education in the UK is devolved to its constituent nations, the TEF is used for the whole the UK creating what Gunn (2016) calls 'the paradoxes of jurisdictional plurality'.

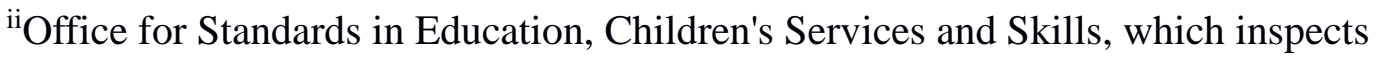
schools and other children's services in England.

iii http://www.academicaudit.net/professor-elizabeth-cleaver.html 1 December 2016
} 